\title{
Litteratur
}

\section{Mogens Müller}

The Expression 'Son of Man' and the Development of Christology. A History of Interpretation. London - Oakville: Equinox 2008, XV + 518 s. (indb.).

Af danske eksegeter, der formår at skrive forskningshistorie, er der frem for alt grund til at nævne Mogens Müller (MM). Det har han dokumenteret nu igen ved bogen The Expression 'Son of Man' and the Development of Christology med undertitlen $A$ History of Interpretation. Der er tale om en forskningshistorie, der strækker sig fra kirkens første tid frem til i dag, idet der dog tages forholdsvis lange skridt i hovedparten af denne periode. Skridtene bliver så naturligt nok kortere, efterhånden som vi kommer frem til vor tid. Litteraturlisten viser, at en hærskares mangfoldighed af forfattere er omtalt. Og så omfatter listen dog langtfra alle udgivelser. I en række ganske omfattende noter er nemlig anført et meget stort antal bøger og artikler, der ikke indgår i litteraturlisten. Man møder også navne på danske bidragydere, der i hvert fald for anmelderen var ukendte.

MM har inddelt sin fremstilling i 18 kapitler. Inddelingen er overordnet kronologisk bestemt, men når det gælder perioden fra midten af det 18 . årh., kommer desuden ønsket om en vis systematisering til at spille en væsentlig rolle. Det afspejles i kapiteloverskrifterne, som er: 1) Early Church, 2) The Son of Man in Gnosticism, 3) Nicene and Post-Nicene Fathers, 4) The Son of Man in Medieval Exegesis, 5) Reformation, Orthodoxy, Counter-Reformation, and Pietism, 6) Enlightenment, Rationalism, and Idealism, 7) Son of Man and the Life of Jesus Project, 8) The Emergence of a Specific Apocalyptic Son of Man Concept, 9) The First Aramaic Stage in the Son of Man Research, 10) The Eschatological Interpretation, 11) Mostly Backwater, 12) The History of Religions School, 13) Interlude, 14) Continuations, 15) The Second Aramaic Stage, 16) Exit the Apocalyptic Son of Man?, 17) Son of Man as a Product of the Gospel Tradition. Kapitlet Conclusion (18) afslutter værket.

Det er velkendt, at der er gjort mange forskellige forståelser af udtrykket Menneskesøn gældende (allerede Augustin kunne opregne mange), men at forståelserne har været så mange, så nuancerede og for nogles vedkommende så indbyrdes uforenelige, som det dokumenteres af MM, kan alligevel godt overraske. Det spørgsmål er da også flere gange blevet rejst, om problemet er uløseligt.

Det er umuligt i en anmeldelse at opregne de mange positioner. Blot følgende. Forskningshistorien viser tydeligt, at det ikke er sådan, at forskellige forståelser af ordet afløser hinanden - at de så at sige har hver deres tid. Derimod er der et sæt af opfattelser, der i lange perioder gør sig gældende med vekslende indbyrdes styrkeforhold. Nok falder der opfattelser fra, men nye kan have vanskeligt ved at trænge igennem. Med 'the first Aramaic stage' 
varsledes der således noget nyt, men det blev hurtigt nærmest kvalt. Men senere i 'the second stage' blev synspunktet gjort gældende med en sådan styrke, at det afgørende kom til præge diskussionen om forståelsen af udtrykket Menneskesøn.

Til yderpositionerne hører den opfattelse, at udtrykket Menneskesøn var en betegnelse for Jesu menneskelige natur, og heroverfor stod den forstålse, at betegnelsen omvendt accentuerede hans guddommelige natur. Den førstnævnte forståelse var den fremherskende i de første adskillige århundreder, men er også gjort gældende af mange fra en senere tid - herhjemme af bl.a. N.F.S. Grundtvig. Den opfattelse, at udtrykket Menneskesøn må forstås i lyset af Dan 7,13 og andre apokalyptiske tekster (især 1 En 37-71 og 4 Ezra 13), bryder for alvor frem i løbet af det 19. årh., selv om der har været tilløb tidligere. Da den religionshistoriske tilgang gjorde sin entre, åbnede der sig nye forståelsesmuligheder. I sidste halvdel af det 19. årh. kom de første tilkendegivelser af, at ordet Menneskesøn skal forstås ud fra aramaisk, nemlig ud fra udtrykket (אר נשי, og blot betyder 'man'. Senere blev det synspunkt fremført med større vægt og virkning. Radikaliteten i dette nybrud fremgår af, at en antagelse af denne forståelse indebærer, at stor set alle andre opfattelser må opgives, dvs. alle de tolkninger, der forudsætter, at betegnelsen Menneskesøn rummer en betydning i sig selv. Om det kommer dertil, må fremgå af den forskningshistorie, der endnu ikke - men måske snart - kan skrives færdig.

Det er et vigtigt anliggende for $\mathrm{MM}$ at vise, at der er en nøje sammenhæng mellem kristologien og forståelsen af udtrykket Menneskesøn. Det kan vel næppe være anderledes, når udtrykket ofte forekommer i evangelierne og er forstået som en af de messianske titler. Der er dog også andre forhold, der har spillet ind - herunder nye fortolkningsmetoder. Fremkomsten af den religionshistoriske og senere af den redaktionshistoriske tilgang er typiske eksempler herpå, og erkendelsen af, at der må sondres mellem den historiske Jesus og den forkyndte Kristus har også været af væsentlig betydning. Det samme har filologiske undersøgelser - ikke mindst det tidligere nævnte synspunkt, at der bag ordet Menneskesøn ligger et aramaisk udtryk, der betydningsmæssigt svarer til et pronomen.

Delbert Royce Burkett udgav for 10 år siden bogen The Son of Man Debate: A History and Evaluation. MM fremfører den kritik af den, at den i for høj grad blot er en katalogisering af synspunkter. Selv om MM lægger vægt på at gøre rede for samspillet mellem forståelsen af begrebet Menneskesøn og kristologien, kan han måske blive udsat for en lignende indvending. Nogle ville nok foretrække lidt færre navne og en fyldigere omtale af de mest fremtrædende repræsentanter for de forskellige forståelsestyper.

Den, der har fornøjelse af at finde trykfejl i (andres) bøger, skal ikke vente sig meget at frydes over af den art i den foreliggende bog. Lidt er der dog at hente, f.eks. hvis man går så vidt som til at se på accentueringen af ordene 
de steder, hvor der forekommer græsk. Et par andre unøjagtigheder skal nævnes. Det skal nok ikke hedde 'the idea of the Son of man idea' (s. 275), og det skal ikke hedde Gretchensfrage, men Gretchenfrage (s. 291). Titlen på Mowinkels bog er ikke Hans som kommer (s. 276). S. 342 skal det være Menschengestalt, og mon ikke s. 273 skulle have været med i registeret s. 499, hvor der er en opregning af de sider, hvor Dan 7,13 er nævnt?

På spørgsmålet, om det er en spændende bog, vil meningerne utvivlsomt dele sig. Forskningshistoriske fremstillinger er normalt ikke just medrivende. Men det er indiskutabelt, at bogen er særdeles informativ. Det er godt, at MM har gjort sin akkumulerede viden om Menneskesønsforskningen tilgængelig for alle.

Helge Kjar Nielsen

\section{Hans-Friedrich Weiss}

Frühes Christentum und Gnosis. Eine rezeptionsgeschichtliche Studie. WUNT 225. Tübingen: Mohr Siebeck 2008. IX + 587 s. € 149 (indb.).

Hans-Friedrich Weiss, fra 1972-94 professor i NT i Rostock, blev 1997 æresdoktor i København. I denne bog vil han besvare det stærkt omdiskuterede spørgsmål om, hvordan man skal forstå forholdet mellem den tidlige kristendom og 'gnosis' eller gnosticismen. Weiss ønsker især at overvinde alternativet førkristelig-efterkristelig. For såvel forestillingen om en relativt udviklet gnosticisme som en af forudsætningerne for nytestamentlig teologi som forestillingen om gnosticismen som et produkt af en ensidig fortolkning af NT er utilfredsstillende. Således konstaterer Weiss i et indledende kapitel om spørgsmålet i forskningen i dag, at den tidligt-kristne gnosis ifølge hans opfattelse ikke blot er opstået som et 'kristent' kætteri eller en sekt, men ud fra en bestemt grundide fremstod som en selvstændig størrelse i forhold til den tidlige kristendom, idet den under sit indtog i denne - sekundært - tilpassede den kristne grundide til sin egen.

Kap. 2 (s. 13-59) gælder urkristendommen og 'gnosis' inden for rammerne af den senantikke religionshistorie, derunder som fænomener af den senantikke 'synkretisme'. En ekskurs er viet “slippery words” som 'gnosis', 'gnosticisme' og 'gnostiker' som selvbetegnelse, idet jo selve terminologien er omstridt. Weiss når her bl.a. ud fra 1 Tim 6,20 til, at det giver god mening at bruge betegnelsen 'gnosis' om den religiøse formation, der gør sig gældende i det 2. årh.

Kap. 3 (s. 61-206) udgøres af en udførlig drøftelse af problemet om en før-kristen 'gnosis'. Den former sig som en gennemgang af kilderne: NT, de anti-gnostiske fædre (ikke mindst Irenæus, Hippolyt og Epifanius), de gnostiske originalskrifter (især biblioteket fra Nag Hammadi) samt de hermetiske og mandæiske skrifter. En længere ekskurs gælder Simon Mager. Weiss mener at kunne konkludere, at kan en førkristen 'gnosis' ikke sandsynliggøres, er det til gengæld muligt at tale om en ikke-kristen 'gnosis', som frem- 